\title{
Käytännöllinen opas surutukea antaville
}

\section{Juha M. Itkonen}

Surun virrassa: Läheisensä menettäneen sielunhoito. Kirjapaja.

224 s. 2019.

Tuha Itkonen väitteli lapsensa menettäneiden vanhempien surusta vuonna 2018. Itkonen on tällä hetkellä kirkkoherrana Tampereella ja tämä kirja on yhdistelmä tutkijan ja papin ääntä. Kirja on hyödyllinen lukukokemus käytännön surutukea antaville.

Kansantajuisesta katsauksesta alan tutkimukseen on hyötyä heille, joilla ei ole aikaa kahlata tutkimusta itse läpi. Tässä osiossa korostuvat ne surututkimukset, jotka liittyvät äkilliseen tai traumaattiseen suruun. Normaali elämään kuuluva suru jää aikaisemman tutkimuksen näkökulmasta vähemmälle huomiolle. Uusin surututkimus puuttuu paljolti listalta, mutta käytännöllisen oppaan tarkoitukseen traumaattisen surun klassikot toimivat oikein hyvin.

Itkonen kehitti jo väitöskirjassaan ns. jaksamisen jakkaran erityisen tuen tarpeessa olevien surevien tunnistamista ja tukemista varten. Tässä kansantajuisessa kirjassa tämän jaksamisen jakkaran esittely on erityisen hyödyllinen, sillä se konkretisoi, miten auttaja voi tukea menetyksen kokeneita ja mitä elämän osa-alueita tämän tuen tulee huomioida. Jaksamisen jakkarassa on neljä jalkaa, jotka muodostavat asiat, jotka tukijan on hyvä huomioida. Ensimmäinen jalka on menetyksen luonne ja tässä osiossa Itkonen korostaa juuri äkillisiä tai traumaattisia menetyksiä, joita varten jaksamisen jakkara on kehitetty. Jakkaran toinen jalka on surevan omat voimavarat, joihin kuuluvat hänen terveytensä ja esimerkiksi aiemmat menetykset. Kolmas jalka on sosiaalinen tuki eli se turvaverkko tai turvaverkon puute, joka menetyksen kokijalla on. Neljännen jalan muodostavat muut samanaikaiset stressitekijät. Surutuen antajat usein kohdistavat huomionsa juuri tapahtuneeseen menetykseen, mutta Itkosen mukaan heidän tulisi huomioida ihminen kokonaisvaltaisemmin ja kysyä myös muista elämässä olevista haasteista. Nämä edellä esitellyt neljä 
jalkaa ovat tietyllä tavalla itsestään selvyyksiä, mutta surevia tukevat eivät aina näitä kaikkia tule huomioineeksi. Tästä syytä on tärkeää, että Juha Itkonen on luonut jaksamisen jakkaran mallinsa ja sen jokaista jalkaa avatessaan nostaa esiin konkreettisia ohjeita, kuinka juuri tätä osa-aluetta tulisi huomioida tukiprosessissa.

Itkosen huomio siitä, että jos surutuki on toimivaa, siitä ei välttämättä saa mitään palautetta, on erittäin tärkeä. Palautetta tulee useimmiten silloin kuin auttaja on tehnyt jotakin, josta tuettava ei pidä. Itkonen jatkaa vielä, että auttajan on kuitenkin hyvä myös keskittyä muistelemaan niitä kertoja, joissa hän itse kokee onnistuneensa surijan tukemisessa. Tämä siksi, että onnistuneet kokemukset auttavat jaksamaan pitkäjänteistä surutukea ja toiseksi auttavat käsittelemään mokia, joita jokainen läheisensä menettäneitä tukeva tekee.

Kirjan viimeinen luku on otsikoitu: Auttajan oma jaksaminen. Tässä osiossa erityisen tärkeää on oman suruhistorian tunteminen. Itkonen kirjoittaa sivulla 211: "omaan suruhistoriaan tutustuminen auttaa myös tunnistamaan, millainen tuki auttaa ja millainen ei."Ja vaikka omasta kokemuksesta ei olisikaan hyötyä tuettavan tukemiseen, parempi oman suruhistorian ymmärrys antaa voimavaroja keskittyä toisen tarinan kuuntelemiseen, kun on itse sinut oman surunsa kanssa.

Monet evankelisluterilaisen kirkon diakoniatyöntekijät ovat surutuen asiantuntijoita ja kohtaavat työssään läheisensä menettäneitä ja pitävät sururyhmiä. Uskon, että Itkosen kirjasta on hyötyä myös kokeneille surutuen antajille. Osa tekstistä on heille tuttua, mutta osa niin pitkään pohdittua ja tutkimukseen pohjaavaan, että tätä kirjaa voi suositella sekä kokeneelle että kokemattomalle surun matkakumppanille. 